\title{
How pupils use a model for abstract concepts in genetics
}

\author{
Grady Venville and Jenny Donovan
}

\author{
University of Western Australia
}

The purpose of this research was to explore the way pupils of different age groups use a model to understand abstract concepts in genetics. Pupils from early childhood to late adolescence were taught about genes and DNA using an analogical model (the wool model) during their regular biology classes. Changing conceptual understandings of the concepts of gene and DNA as a result of the teaching that incorporated the model were investigated. The research design was a multiple case study enacted in four classes (Year 2, Year 5, Year 9 and Year 12). In each class, the teacher used the same wool model to engage pupils in learning about genes and DNA. The results suggest that the role of the wool model was largely determined by the pupils' prior knowledge. The model was malleable and had multiple roles in the teaching and learning process that reflected the pupils' developing conceptual understandings about genes and DNA.

Key words: Analogical model; Genetics; Conceptual development.

\section{Introduction}

Models and analogies are useful for transforming abstract, unfamiliar and seemingly incomprehensible ideas, concepts and theories into an intelligible realm of understanding for people in many contexts and circumstances. Science is a field replete with ideas that are difficult to visualise and often counterintuitive for pupils of all ages. It is not surprising, therefore, that models and analogies are important tools in the classroom repertoire of reputable science teachers (Harrison and Coll, 2008; Treagust, Duit, Joslin and Lindauer, 1992). Not only do science teachers, science textbooks and lab manuals utilise models and analogies to captivate the conceptual attention of pupils (Aubusson, Harrison and Ritchie, 2006; Thiele, Venville and Treagust, 1995), but science-based television programmes and computer software abound in graphical representations of scientific phenomena. Little is known, however, about how models and analogies are used by pupils of different ages. We know little about the way young children in the early years of primary school are able to use models to understand scientific concepts compared with pupils in the final years of high school, or about how model-building capacity develops between these ages.

The purpose of the research presented in this paper was to begin to explore the ways that models are used by pupils of different ages to understand science concepts. In order to do this, pupils from early childhood to late adolescence (Years 2, 5, 8 and 12) were exposed to an analogical model (the wool model) for genes and DNA during their regular biology classes. The pupils' changing conceptual understandings of the concepts of gene and DNA as a result of the teaching that incorporated the model were investigated. More specifically the research questions were:

1. What changes occurred in pupils' conceptions about genes and DNA?

2. What role did the wool model play in effecting those changes?
In this paper we use the term 'model' in a similar way to Justi and Gilbert (2006). A model is the result of using a more familiar entity to represent an aspect of reality (such as an object, event, process or idea) through the production of analogy. Analogy is the expression of a relation of equivalence or likeness. The term analogical model is used for models that are elaborated to explain several aspects or features of the reality being represented.

\section{Theoretical framework}

Entities such as atoms and viruses that cannot be seen with a light microscope, invisible processes such as magnetism and electricity, explanatory concepts such as food chains and the mole, and theories such as evolution and the kinetic theory of matter - all are modelled in some form or another by teachers of science throughout the world. Models and analogies can be used to gain pupils' attention, to organise their thought processes, to improve their self-efficacy, to motivate and, most importantly, to help them understand science (Dagher, 1994; Duit, 1991; Harrison, 2008).

The science education community's understanding of the role of models and analogies in helping pupils to better understand science is, however, far from complete. It has been argued, for example, that the use of analogies and models is not suitable for pupils who do not think in a formal operational way (Piaget and Inhelder, 1974; 1976). Pupils with formal operational thought patterns are capable of grasping abstract principles, inter-related causes and multiple perspectives. According to Piaget and Inhelder $(1974 ; 1976)$ the change from concrete operations to formal operational thought happens to some, but not all, pupils at about the age of 14 .

In a study of reflective abstraction published in 1977, and later analysed and reported by Wadsworth (2004), Piaget examined children's understanding of analogies. He found that children of ages five and six could group things that were similar but could not explain a reason for the groupings. For 
example, they could put a picture of a dog with hair and a picture of a bird with feathers, but they would say that a dog needs hair to keep warm and a bird needs feathers to fly. The relationship between the dog and the hair was not compared with the relationship between the bird and the feathers. Older children of approximately 11 years of age and older were able to consciously explain the hierarchical relation and consider both parts of the analogy. That is, they could explain that both the dog and the bird have a body covering that helps to keep them warm and that the dog has hair just like the bird has feathers. Wadsworth (2004) concluded that analogical reasoning is not available to children until the stage of formal operations when children are able to use analogical rules and articulate the form of the analogy.

As a consequence of this research by Piaget and subsequent analysis by others, the use of analogical models to explain science in school is not a straightforward issue (Harrison, 2008). On one hand, it is plausible that pupils who do not have formal operational thought patterns are incapable of using models and analogies because the process of drawing comparisons (analogies) between two scientific phenomena is an abstract process in itself. On the other hand, it also is plausible that models, particularly those of a concrete, hands-on nature, may have much to offer pupils who cannot comprehend abstract scientific concepts. Concrete models may be a useful tool to help pupils of a very young age visualise non-observable, explanatory phenomena such as disease causing bacteria, the day/night cycle and genes and DNA. Harrison (2008) suggests that younger children will benefit most from concrete analogies that they can see and feel. When abstract thinking emerges, around adolescence, abstract analogies may become useful to teachers and their pupils. Harrison cautions teachers, however, that even older pupils may not possess the necessary visualisation skills to utilise verbal and abstract analogies.

These issues present an interesting conundrum. Should teachers use analogical models to teach abstract and difficult concepts to young children, or are they wasting their time if they do? The findings of this research begin to give us insights into the role that models have in making science comprehensible to pupils of a broad range of ages. This in turn, will begin to give us useful information about when and how it is appropriate to use models in the teaching of science.

\section{Method}

The research design was a multiple case study (Merriam, 1998; Yin, 2003) enacted in four classes (Year 2, ages 6 and 7; Year 5, ages 9 and 10; Year 9, ages 13 and 14; and Year 12, ages 16 and 17) that used the same wool model to learn about genes and DNA. The classes were selected so that teachers with high levels of biological, pedagogical content knowledge participated in the study. Intervention lessons that focused on developing the pupils' understanding of genes and DNA using the wool model were designed by one researcher in collaboration with the regular classroom teacher to augment each teacher's life science programme for the term. Data collection included pupil pre- and post-instruction interviews and reflective lesson notes from the teacher who taught the wool model to each class. A summary of the pre-instruction interview data was provided to the classroom teacher and used to inform the development of the intervention lessons.

The interview protocol was similar to that used in previous work with 10 to 15 year-old children (Venville, Gribble and Donovan, 2005). The first part of the interview aimed to determine whether the interviewee could differentiate between genetically inherited traits and socially and culturally acquired traits. Part 2 of the interview aimed to determine the interviewee's understandings of how and why offspring resemble their parents. That is, to probe for knowledge of related mechanisms such as genes and DNA. The aim of the third part of the interview was to determine the interviewee's conception of the means of genetic inheritance. If the pupil had either mentioned or heard of genes or DNA, they were asked questions such as: 'Where do you think genes are in the body?' 'What do you think genes look like?' and, 'How do you think genes work?' This third section of the interview was expanded post-intervention to help determine the role of the wool model in developing the pupils' conceptions of genes and DNA.

Approximately one third of pupils in each class were interviewed. Interviewees were selected in collaboration with the classroom teacher so that pupils from a range of science attainment levels were included. Moreover, pupils who were considered by the teacher to be likely to be comfortable with the interview process and able to articulate their ideas about science were selected. Due to absences during lessons or during interviews (particularly in the Year 9 class), some pupils were only interviewed once. These pupils were not included in the analysis presented in this paper. The final numbers of pupils for each year for whom we had a full set of data can be seen in Table 1. Data from the interviews were captured using interview response sheets as well as audio-tape recording.

Quantitative data analysis involved calculating a pre-instruction and post-instruction score for each pupil in each class, based on their responses recorded on the interview response sheets. The score was calculated by awarding zero points for no or limited understanding, one point for partial understanding and two points for good understanding in each of five criteria about pupils' understanding of genes and DNA. The maximum total score was 10 points. The five criteria, in increasing order of conceptual difficulty, were:

1. differentiation between biological and cultural inheritance

2. association of genes and/or DNA with inheritance

3. knowledge of the relationship between genes and DNA (i.e. that DNA is the chemical of genes)

4. knowledge of the nature of genes and/or DNA (e.g. it's in the cells of the body and determines phenotype)

5. knowledge of a mechanism of action (i.e. that DNA produces proteins and proteins determine phenotype).

Scoring was conducted by two researchers in collaboration for the Year 9 pre- and post-instruction interviews and for the Year 2 pre-instruction interviews so that a consistent approach to scoring was achieved. For example, for Criterion 1, pupils who were able to explain that an adopted child would develop to look like their biological parents, but use the language of their adopted parents, and also explain that a tiger brought up by a dog would growl like a tiger were given two points for a full understanding of the difference between biological and cultural inheritance. Pupils who could answer these questions correctly in the human context, but not in the animal context, were given one point for partial understanding, while pupils who showed confusion even in the human context were given zero points for limited or no 
understanding. The remainder of the interviews were scored by one researcher. All pupils from all year groups were scored in the same way. Results of this quantitative analysis are presented in Table 1 in the findings.

The quantitative analysis gave initial insights into the data and potential themes were generated by the two researchers about the role of the wool model for the pupils in each of the classes that would be potential answers to Research Question 2. These themes were as follows:

- For Year 2 the role of the wool model was to provide the pupils with a concrete image of a mechanism to explain the known process of biological inheritance.

- For Year 5 the role of the wool model was to change the way they viewed DNA from its usefulness to society (e.g. identification of criminals) to its biological function (i.e. to pass information from one generation to the next about how living things are formed).

- For Year 9 the role of the model was to coalesce the divergent concepts of gene and DNA,

- For Year 12, it was to create a network of understanding between previously isolated pieces of information such as gene, DNA and protein.

Once the themes were generated, the fully transcribed interview data and teachers' reflective diary data were searched for confirming and disconfirming evidence. A great deal of confirming evidence and some disconfirming evidence was found. The pupil interview data and the teachers' reflective lesson notes were used to revise the themes generated about the role of the wool model in the observed changes to pupils' understanding. Qualitative evidence is provided in the form of excerpts from the student interviews and teachers' notes in the findings section. Excerpts were selected as representative of the most common findings from the detailed quantitative analysis (i.e. confirming evidence), but also to demonstrate how the qualitative data changed the themes (i.e. disconfirming evidence) that were initially generated from the interview summaries.

\section{The wool model}

The wool model was used in all four classes, but the teacher was encouraged to adapt its use depending on the pupils' pre-instruction interviews. Here we will give a brief overview of the nature and scope of the wool model that is outlined in Figure 1. The wool model consisted of several pieces of different coloured wool knotted together into one length. The wool itself represented DNA, each of the coloured sections of wool represented genes and the whole length of six coloured wool 'genes' represented a chromosome. Pupils were given two lengths, (chromosomes), one that was already knotted together and one that they had to construct. The two lengths of knotted wool represented an homologous pair of chromosomes. The homologous chromosomes (two lengths of wool) had the same genes (coloured sections of wool), but they could have different shades of each colour. The different shades of each colour of wool represented different 'alleles' of each gene. There are several differences where the wool model breaks down (Figure 1) and these were explained to the pupils as the teachers felt necessary.

\section{Results}

Findings from the quantitative analysis of the interviews are presented in Table 1. Answers to Research Questions 1 and 2

\begin{tabular}{|c|c|}
\hline Wool Model & Target Concept \\
\hline \multicolumn{2}{|c|}{ Similarities } \\
\hline Woollen yarn & DNA \\
\hline $\begin{array}{l}\text { Pieces of different coloured } \\
\text { wool tied together into a } \\
\text { long thread }\end{array}$ & $\begin{array}{l}\text { Genes in sections along } \\
\text { DNA }\end{array}$ \\
\hline $\begin{array}{l}\text { Different shades of same } \\
\text { colour wool }\end{array}$ & Different alleles \\
\hline One long thread of wool & Chromosome \\
\hline Two long threads of wool & Paired chromosomes \\
\hline \multicolumn{2}{|c|}{ Differences } \\
\hline $\begin{array}{l}\text { Easily observable with } \\
\text { naked eye }\end{array}$ & $\begin{array}{l}\text { Not visible with light } \\
\text { microscope }\end{array}$ \\
\hline $\begin{array}{l}\text { Discrete sections of coloured } \\
\text { wool represent genes }\end{array}$ & $\begin{array}{l}\text { Genes are not necessarily } \\
\text { discrete sections of DNA }\end{array}$ \\
\hline $\begin{array}{l}\text { Alleles represented by } \\
\text { different shades of colour }\end{array}$ & $\begin{array}{l}\text { Alleles formed by } \\
\text { different chemical } \\
\text { composition of DNA }\end{array}$ \\
\hline
\end{tabular}

Figure 1. An outline of the similarities and differences between the analogical wool model and the target concepts in genetics.

are summarised and presented in Table 2. In the following paragraphs we will examine the results from each of the classes in more detail.

\section{Modelling in Year 2: providing a concrete image and language}

Prior to the intervention, none of the Year 2 pupils $(n=14)$ referred to genes or DNA as an entity associated with inheritance. In the post-intervention interview, seven of the 14 interviewees spontaneously mentioned genes, DNA or chromosomes as something that contributed to inheritance. The majority (8/14) of the pupils were able to recall that the wool in the model represented DNA and 12 of the 14 pupils understood that living and/or once living things have genes and/or DNA.

The transcript excerpts included below are from the preand post-instruction interviews with Daris, a pupil from the Year 2 class. The excerpts show how the interviews probed the pupil's knowledge of concepts related to inheritance such as genes, DNA and chromosome, before and after the intervention lessons. The excerpts show that prior to the intervention, Daris had not heard of the terms gene, DNA or chromosome. After the intervention, he referred to DNA as something that makes kittens look like their parents.

Pre-instruction interview excerpt with Daris (Year 2)

[Interviewer and pupil are looking at pictures of dogs and

Table 1. Results of the quantitative analysis of the interview. All scores are out of 10 .

\begin{tabular}{lcc}
\hline Class & $\begin{array}{l}\text { Pre-instruction } \\
\text { mean (SD) }\end{array}$ & $\begin{array}{l}\text { Post-instruction } \\
\text { mean (SD) }\end{array}$ \\
Year 2 $(\mathrm{n}=14)$ & $1.3(1.2)$ & $5.1(1.8)$ \\
Year 5 $(\mathrm{n}=12)$ & $4.3(2.2)$ & $8.8(1.4)$ \\
Year 9 $(\mathrm{n}=7)$ & $5.8(0.9)$ & $7.1(0.7)$ \\
Year 12 $(\mathrm{n}=10)$ & $7.4(0.5)$ & $8.7(1.1)$ \\
\hline
\end{tabular}


Table 2. An outline of answers to Research Questions 1 and 2 showing the changes that occurred in pupils' conceptions and the initial and refined themes about the role of the wool model for each year group.

\begin{tabular}{|c|c|c|c|}
\hline Class & $\begin{array}{l}\text { Research Question 1: What changes } \\
\text { occured in pupils' conceptions about genes } \\
\text { and DNA? }\end{array}$ & $\begin{array}{l}\text { Research Question 2: What role did the } \\
\text { wool model play? } \\
\text { Initial Themes }\end{array}$ & Revised Themes \\
\hline $\begin{array}{l}\text { Year } 2 \\
(n=14)\end{array}$ & $\begin{array}{l}\text { Prior to instruction pupils understood } \\
\text { biological inheritance but none } \\
\text { had heard of genes or DNA. After } \\
\text { instruction, seven pupils spontaneously } \\
\text { mentioned genes or DNA as a } \\
\text { mechanism for biological inheritance. }\end{array}$ & $\begin{array}{l}\text { For the Year } 2 \text { pupils the wool model } \\
\text { provided a concrete image of a } \\
\text { mechanism (genes and DNA) to explain } \\
\text { the known process of inheritance. }\end{array}$ & $\begin{array}{l}\text { For the Year } 2 \text { pupils the use of the wool } \\
\text { model provided a concrete image and } \\
\text { the language to describe a previously } \\
\text { unknown mechanism (genes and DNA) } \\
\text { for the known process of inheritance }\end{array}$ \\
\hline $\begin{array}{l}\text { Year } 5 \\
(n=12)\end{array}$ & $\begin{array}{l}\text { Prior to instruction most pupils had } \\
\text { heard of DNA (some had heard } \\
\text { of genes) but thought it was an } \\
\text { identification tool used for crime but } \\
\text { also that it exists in non-biological things } \\
\text { like computers and cars. }\end{array}$ & $\begin{array}{l}\text { For the Year } 5 \text { pupils the wool model } \\
\text { changed the way pupils viewed } \\
\text { DNA from its usefulness to society } \\
\text { (e.g. identification of criminals) to } \\
\text { its biological function (i.e. to pass } \\
\text { information from one generation to the } \\
\text { next). }\end{array}$ & $\begin{array}{l}\text { For Year } 5 \text { pupils the role of the } \\
\text { wool model was to develop an } \\
\text { association between the concepts } \\
\text { of gene and DNA, living things } \\
\text { and biological inheritance. For } \\
\text { both Year } 9 \text { and Year } 5 \text { pupils } \\
\text { the wool model coalesced the }\end{array}$ \\
\hline $\begin{array}{l}\text { Year } 9 \\
(n=7)\end{array}$ & $\begin{array}{l}\text { Prior to instruction } 6 \text { out of } 7 \text { pupils } \\
\text { spontaneously mentioned genes or } \\
\text { DNA as a mechanism of inheritance. } \\
5 \text { out of } 7 \text { pupils said genes and DNA } \\
\text { are different things: genes are passed on } \\
\text { from parents, DNA is for identification. } \\
\text { After instruction all pupils understood } \\
\text { that both genes and DNA are } \\
\text { responsible for characteristics. }\end{array}$ & $\begin{array}{l}\text { For the Year } 9 \text { pupils the wool model } \\
\text { coalesced the divergent concepts of gene } \\
\text { (thing that makes you look like your } \\
\text { parents) and DNA (thing that can be } \\
\text { used to identify you) into single concept } \\
\text { (thing that influences characteristics). }\end{array}$ & $\begin{array}{l}\text { that makes you look like your } \\
\text { parents) and DNA (thing that } \\
\text { can be used to identify you) } \\
\text { into a single concept (thing that } \\
\text { influences characteristics). }\end{array}$ \\
\hline $\begin{array}{l}\text { Year } 12 \\
\text { (Biology } \\
\text { class) } \\
(\mathrm{n}=10)\end{array}$ & $\begin{array}{l}\text { Prior to instruction only one pupil } \\
\text { understood that DNA makes proteins. } \\
\text { After instruction five pupils fully } \\
\text { understood relationship between genes } \\
\text { \& DNA, other pupils made positive } \\
\text { association, five pupils understood } \\
\text { DNA forms a code which produces } \\
\text { proteins, all pupils related genes and } \\
\text { characteristics }\end{array}$ & $\begin{array}{l}\text { For the Year } 12 \text { pupils the wool } \\
\text { model created networks of knowledge } \\
\text { between previously isolated pieces of } \\
\text { information e.g. gene, DNA, protein and } \\
\text { characteristics. }\end{array}$ & $\begin{array}{l}\text { For the Year } 12 \text { pupils the wool model } \\
\text { initiated and consolidated initial } \\
\text { networks of understanding between } \\
\text { concepts of gene, DNA and allele, and } \\
\text { preceded further network creation to } \\
\text { protein synthesis and characteristics. }\end{array}$ \\
\hline
\end{tabular}

\section{puppies.]}

Interviewer: Do you think any of those adults and puppies are related? Do you think any of those puppies belong to any of those adult dogs?

Pupil D: That one and that one [pointing to a white dog and puppy].

Interviewer: And how do you know that?

Daris: Because they are both white.

Interviewer: Both white. Anything else?

Daris: They look the same.

Interviewer: So do you think that's a common thing, that babies look like the parents?

Daris: Yes.

Interviewer: Okay. Have you any idea why that happens - why babies look like parents?

Daris: No.

Interviewer: All right, I'm going to ask you about three different words now. It's okay if you haven't heard of them, I just want to know if you have. Have you heard of the word gene

- g, e, n, e - gene?

Daris: No.

Interviewer: What about a big word - chromosome?

Daris: No.

Interviewer: What about DNA?

Daris: No.

Interviewer: That's fine, we might hear about those when we do more lessons with [Teacher].

Post-instruction interview excerpt with Daris (Year 2)

[Interviewer and pupil are looking at pictures of cats and kittens.]

Daris: That one and that one are babies.

Interviewer: They're babies, okay. So let's take this kitten [orange kitten]. Can you see a cat on that page that could be its Mummy or Daddy?

Daris: [Daris points to orange, adult cat].

Interviewer: That one! Okay, I've just got to write down which one you picked. [top right cat with top left kitten]... Why do you think that one could be its Mummy or Daddy?

Daris: Because they are the same colour and they look the same.

Interviewer: Okay, Daris. Can you tell me what makes them look similar to each other?

Daris: The same DNA.

When interviewed prior to instruction, Daris had no idea what makes puppies look like their parents. Moreover, he had never heard of the words genes, DNA or chromosome. After instruction, however, he spontaneously mentioned DNA when asked what makes kittens look similar to their parents. It seems that the wool model not only provided him with a concrete image of something that makes offspring look like 
their parents, but also provided him with appropriate vocabulary. This idea is supported by a number of comments from the Year 2 teacher's reflective lesson notes included below.

The focus of this lesson was to extend their ideas about the characteristics of living things and an introduction of the terms DNA, GENE, ALLELE and CHROMOSOME.

Nearly all the children had demonstrated a concept of family resemblance, but none of them knew how it was achieved. I told them that's what I was going to explain to them now. They seemed very attentive at this point, as if I was going to unveil a great mystery.

On the board I had written the terms DNA, GENE, $A L$ LELE and CHROMOSOME.

By the end of the lesson, they were able to relate the words DNA, GENE, ALLELE and CHROMOSOME to the appropriate parts of our wool model and seemed to understand that this was an important feature of living things. (Excerpts from Year 2 teacher's reflective notes)

The Year 2 teacher's notes show that she was focused on the terminology of genetics. She carefully put the new words on the board and expressed her observation that, by the end of the lesson, the pupils could connect the terminology with parts of the wool model. Even the capitalisation of the terms by the teacher in her reflective notes indicated the importance of language in this lesson.

Our initial theme, based on the quantitative data, was that the role of the wool model for many of these very young children was to create a concrete image of things they had never heard of - genes and DNA - that make babies look like their parents (Table 2). Based on close examination of the qualitative data, we revised this theme to indicate that the wool model also provided the pupils with new vocabulary to explain their ideas in ways they were previously unable to do (Table 2).

\section{Modelling in Year 5: broadening the concept of DNA}

Prior to instruction, about half the Year 5 pupils (seven of 12) had heard of DNA, but few had heard of genes. Pupils who had heard of DNA tended to associate it with the identification of people in crimes, paternity cases and disasters. They thought that DNA was located either in the blood or on external parts of the body such as the fingers, feet or hair. Some of the Year 5 pupils (four of 12) thought that DNA could be found in inorganic things such as cars and computers, or were not sure. Post-intervention, the Year 5 pupils were better able to explain that only living and once-living things contain DNA and genes.

Peta was one of the pupils in this Year 5 class who, prior to instruction, had not heard of genes, but thought she might have heard of DNA, although she could not explain anything about it.

Pre-instruction interview excerpt with Peta (Year 5)

Interviewer: Which adults and puppies are related?

Peta: That one and that one [correctly pointing out two related dogs].

Interviewer: So how did you know that?
Peta: Because they are the same colour and have the same face.

Interviewer: Same colour and face, okay. So you've now told me that in people, tigers and dogs, babies look like their parents. What is it that makes babies look like their parents?

Peta: Um, they are produced from their parents.

Interviewer: Okay. Do they have anything they get from their parents which might make them look the same?

Peta: Not that I know of.

Interviewer: Okay, have you ever heard the word genes? I don't mean denim jeans, I mean genes with a 'g'.

Peta: No, I might have seen it in a book, but I don't know the word genes.

Interviewer: Okay, how about the word DNA?

Peta: Yes I think so.

Interviewer: Okay so have you any idea what genes or DNA do?

Peta: No.

Interviewer: Okay, have you any idea where they are in the body?

Peta: No.

Interviewer: Okay, have you any idea if they are the same or different?

Peta: No.

Interviewer: Okay, that's fine.

Post-instruction interview excerpt with Peta (Year 5)

Interviewer: Can you pick out a cat and a kitten that might be related?

Peta: Yes, these two [matched two tortoiseshells].

Interviewer: And why do you think they are related?

Peta: Because they are the same colour and have the same shaped face.

Interviewer: Okay, so what is it that they have that makes them look the same as each other?

Peta: Their DNA.

Later in the interview:

[Interviewer and pupil are looking at the wool model]

Interviewer: So can you tell me what this whole strand of wool represents? If you're not sure how to say some of the words you can just point [to the words on a card].

Peta: The DNA.

Interviewer: Okay. Why did we have different colours on our model?

Peta. The different genes.

Interviewer: And do you remember that we had two different forms of some colours, like here are the two different pinks. What name did we give to the different forms of the genes?

Peta: I can't remember.

Interviewer: Thinking back to living, once-living and non-living things, which types of things would contain genes and DNA?

Peta: Living things.

Interviewer: Would the once-living things contain it?

Peta: No.

Interviewer: What about non-living things?

Peta: No.

Interviewer: Can you remember what a gene does?

Peta: I think it was the gene that made us look like our Mum and Dad.

Interviewer: Would your DNA be exactly the same as anyone 
else's in your class?

Peta: No.

Interviewer: Can you name a person who would have DNA similar to yours?

Peta: My family.

Interviewer: Who in particular in your family?

Peta: My Mum.

In the first part of the post-intervention interview, Peta was able to explain that it is DNA that makes kittens look like their mother. Later, using the wool model, she was able to explain that genes are different parts of the DNA strand and that genes make people "look like our Mum and Dad". She also understood that living things have DNA, and not nonliving things, but thought that once-living things would not have DNA. Evidence from the interview also indicated that Peta confused the terminology for alleles and chromosomes. Terminology mistakes aside, the wool model enabled Peta to develop an association between the concepts of gene and DNA, living things and biological inheritance. The teacher commented in her reflective lesson notes that this was something that she had aimed to achieve:

I explained [to the pupils] I would use a model to show them how DNA and genes were inter-related and worked to bring about family resemblances. There were other models in the science room, so it was easy to remind them what a model does in terms of making something we can't see more understandable. (Excerpt from Year 5 teacher's reflective notes)

The role of the wool model for the Year 5 pupils was to broaden the way they viewed the concept of DNA. They began to understand the biological function of DNA in that it was related to the way we resemble our parents and that it is a concept closely related to the concept of genes (Table 2).

\section{Modelling in Year 9: coalescing divergent concepts}

Prior to the intervention, the majority of the Year 9 (six of seven) pupils had heard of genes and/or DNA. Of the pupils who had heard of genes and/or DNA, those that had any functional explanation generally said genes were something passed on from your parents to make you look the way you do, and that DNA was something that makes you different from everyone else. Many Year 9 pupils (five of seven) thought that genes and DNA were different things with different functions. Post-instruction, the Year 9 pupils were better able to explain that DNA is the chemical that makes up genes, like the wool in the model. They also were better able to explain that genes and DNA are responsible both for making us look like our parents, as well as making us unique from other individuals. Excerpts from Jamie's interviews show he was fairly typical of the Year 9 pupils who participated in this study.

Pre-instruction interview excerpt with Jamie (Year 9)

Interviewer: What makes you look like Mum and Dad?

Jamie: Don't know.

[Later in the interview when he said had said he had heard of genes and DNA]

Interviewer: What have you heard about genes and DNA?

Jamie: DNA is like when you try like ... someone's passed away and you try and see if they are related to your family. Genes are like ... always passed on or something.

Interviewer: Where in the body do you think genes are?

Jamie: In the look of the person, or the personality or something.

Interviewer: Any idea how it works?

Jamie: No, I heard it before but I forgot.

Interviewer: Do you think DNA and genes are the same thing or different things?

Jamie: I think they're two different things.

Interviewer: Have you got any ideas why you think that?

Jamie: 'Cos genes like ... genes are passed on, but DNA ... not sure about passing it on ... yes, I think DNA is for like... that's your baby, it's for identifying.

\section{Post-instruction interview excerpt with Jamie (Year 9):}

Interviewer: What makes them look the same as each other? [referring to cats]

Jamie: It's the parents that brought them up, that had them ... their genes.

[With reference to the wool model]

Interviewer: What does the whole strand of wool represent? Jamie: DNA.

Interviewer: What does each colour represent?

Jamie: The gene.

Interviewer: If we look at the pinks [in the wool model], we can see there are two forms. What name is given to these two forms?

Jamie: They're alleles.

Interviewer: And how many genes have we got on the whole DNA strand?

Jamie: I think there's six genes, yeah six.

Interviewer: What types of things contain genes and DNA?

Jamie: Humans, animals, plants could ...' 'cos like they have...

Interviewer: Humans, animals and plants, okay, and can you remember anything about what a gene does?

Jamie: Doesn't it make us look the same as our parents?

Interviewer: So would your DNA be exactly the same as anyone else's in your class?

Jamie: No, we all have different DNA, because they're not family.

Interviewer: Is there anyone in your family whose DNA would be identical to yours?

Jamie: Not exactly identical, a little bit different.

Interviewer: Can you name a person whose DNA would be similar, but not exactly the same as yours?

Jamie: Most probably my Dad.

Before instruction, Jamie clearly had divergent concepts for gene and DNA, as did many of the Year 9 pupils. While he was not asked specifically in the post-instruction interview if genes and DNA are different, he was able to link genes and DNA through the wool model and expressed his understanding that the wool represented DNA, that the coloured sections represented genes and that genes make us look like our parents. The Year 9 teacher explained in her reflective lesson notes that an important part of her approach to the lesson was for the students to understand the relationship between genes and DNA.

The disruption was bad. Being the end of term, it was hard 
to maintain any kind of flow... I did eventually cover all the points on my list but there would be no presumption that anything much has been learned. The main thing I tried to get across was the relationship between genes and DNA. Those that took an interest seemed to enjoy the wool mod$e l$, and everyone enjoyed stringing all the DNA together at the end and putting it up around the classroom. Hopefully that will be a visual reminder of the concepts I had attempted to introduce. I think the model has a lot of explanatory power. (Excerpt from Year 9 teacher's reflective notes)

Based on the interview data and the teacher's reflection, the role of the wool model for many of the Year 9 pupils was to coalesce the divergent concepts of gene and DNA.

\section{Modelling in Year 12: creating networks of concepts}

While the majority of Year $12(n=10)$ pupils had heard of concepts such as gene, DNA, chromosome and allele prior to instruction and knew that these structures are in cells, few clearly understood the relationships between them. For example, they knew where DNA was located and had some idea of the double helix structure from relatively recent teaching, but were not able to explain how DNA actually produces particular characteristics in the organism. Post-instruction interviews showed that the Year 12 pupils developed a sound understanding of the relationship between DNA, gene, allele and chromosome and a better understanding of the link from DNA to protein, but not necessarily from protein to characteristic. The role of the wool model for many of the Year 12 pupils seemed to be to create networks of understanding between isolated pieces of information they had learnt in biology class.

Pre-instruction interview excerpt with Rena (Year 12)

Rena: What they look like? OK, well chromosomes are threadlike is it? They're not visible when it's in interphase, but when it starts division they become visible, they thicken up, a spiral shape and after the cell has divided, they shrink. Interviewer: What about genes?

Rena: No, I don't know.

Interviewer: What about DNA?

Rena: DNA is a spiral, combined the two ... I don't know the name ... helix? Yes, a double helix.

Interviewer: So how does the DNA work? How does it make the features similar to the parents? How does it make the fur a particular colour for example? [referring back to dogs]

Rena: Oh they switch some genes on and some genes off in particular cells. For example in cells for eye colours, they switch the brown colour on so the brown comes up.

Interviewer: Are genes and DNA the same thing or different things?

Rena: Genes are made up from DNA so they are similar ... so ... genes are made up of DNA.

Post-instruction interview excerpt with Rena (Year 12)

Interviewer: What is the function of DNA?

Rena: It produces the proteins which are made of amino acids. Interviewer: How does it do that? What is special about the DNA molecule?

Rena: There's a gene, there's some code that tells ... the first three tells you the ... is the code for the thing ... there's a stop and a start, and following on, you take three bases each and that tells you the code. That puts the amino acids in the right order.

Prior to instruction Rena could describe DNA but not genes, even though she understood that genes are made up of DNA. She did not know how DNA made dogs look like their parents. After instruction Rena had made the connection between the code in DNA and the production of proteins.

Pre-instruction interview excerpt with Emily (Year 12)

Interviewer: What do genes and DNA look like?

Emily: DNA is hard to explain, like when it's flat it's like a ladder, but when it's twisted around it's a chromosome, I think. I'm not sure on that.

Interviewer: Can you describe a gene?

Emily: A gene is just what you call ... they've got sort of bases and a certain number of bases makes up a gene. It's not like an actual thing.

Interviewer: So how do they work?

Emily: What happens is ... you have the DNA and the genes ... and certain things switch off ... I've forgotten. I know sort of what happens but I don't know specifics ... so something might be happening different with one to make blue eyes and one might have something different, like switched off. That's how I remember it.

Interviewer: So would you say that genes and DNA are the same thing or different things? What is the relationship between genes and DNA?

Emily: DNA is instructions to make the genes have certain characteristics.

Post-instruction interview excerpt with Emily (Year 12)

Interviewer: What is the function of DNA?

Emily: It's basically controlling cell functions.

Interviewer: How do you think it does that?

Emily: By creating proteins.

Interviewer: Yes, and how does it actually do that?

Emily: I think the messenger RNA, which is a copy of the DNA, goes out into the cytoplasm.

Interviewer: Yes it does, but what is it about the DNA that helps it make proteins?

Emily: Oh, it has genes - the bases are in a special sequence as a code.

Prior to instruction, and in a similar way to Rena, Emily could describe switching genes on and off but could not describe what they do to have an impact on the way that organisms develop and look. After instruction, Emily was clearly able to make the link between the network of concepts of genes, DNA and proteins.

In her reflective lesson notes, the Year 12 teacher commented that the relationship between genetics concepts was an important aspect of her teaching.

The lesson was too long, went into lunchtime a bit, but I expected there to be too much... I particularly hammered the relationship between DNA - alleles - proteins - characteristic... They took a while to interact with the model, seemed a bit uncertain about handling it, and altering it by knotting the second strand. However, once I got them started by looking at the questions, they got into stride. It 
really helped them to understand the relationship of genes and alleles, especially when we looked around the class at the other chromosomes. (Excerpt from Year 12 teacher's reflective notes.)

The teacher's lesson notes indicated that the wool model was used to review the relationship between DNA, gene, allele and chromosomes, and that the connection with proteins and characteristics came through a class discussion of biochemical pathways and how mutations can result in diseases like albinism, cretinism and alkaptonuria. The headings from the teacher's lesson notes below show this lesson procedure.

DNA Structure Review

Protein Structure Review

Relationship between DNA, Gene, Allele and Chromosomes Check out this Model using Yarn

Biochemical Pathways

(Headings from Year 12 teacher's lesson notes.)

\section{Discussion}

Table 1 provides quantitative evidence that pupils' conceptions of genes and DNA were different for each of the year groups and that their understandings were increasingly sophisticated as the children were older. Moreover, there is evidence that instruction, including the use of the wool model, did result in some change in pupils' understanding of these concepts. The qualitative analysis of interviews generally supported the themes generated from the quantitative data.

The qualitative data did suggest subtle differences in the role of the wool model that were not evident in the initial themes. For example the initial theme for the Year 2 class was that the model would provide a concrete image for the pupils to visualise a mechanism for inheritance (Table 2). The qualitative data, as in the interview excerpt from Daris and the teacher's reflective notes, showed the importance of language. None of the Year 2 children had heard of genes and DNA prior to instruction, but after instruction many of them were able to reproduce the terms genes and/or DNA when discussing why baby cats look like their mother. While the Year 2 pupils learnt terms to describe something that is related to inheritance, and they could associate that terminology with the wool model, we are not sure whether they were able to link those ideas with something in the body. At this very young age, however, simply learning language that will enable the development of their concept of inheritance can be considered important. Although we initially felt that the wool model would provide a concrete image of a mechanism of inheritance for these pupils, we finally came to the conclusion that the language was also an important issue and, as demonstrated by the teacher's reflective notes, the wool model supported the introduction of the language of genetics (Table 2).

The quantitative analysis (Table 1) showed a comparatively large difference between the Year 5 and Year 9 pre-instruction interview scores (4.3 and 6.1 respectively). The qualitative analysis, however, suggested that the conceptual differences between the pupils in these two years were not so evident. This may be reflected in the high standard deviation for the Year 5 pre-instruction scores (Table 1). Some of the Year 5 pupils, like Peta, had not heard of genes and DNA, and scored lower on the quantitative analysis. For those Year 5 children who had heard of genes and DNA, their ideas were not very different compared with the Year 9 pupils. Both groups of pupils tended to differentiate DNA and genes, associating genes with inheritance and DNA with identification. While we did initially suggest different roles for the wool model for Year 5 and Year 9 pupils (Table 2) we eventually concluded that the wool model played a part in broadening the concept of DNA and coalescing the concepts of gene and DNA for both the Year 5 and the Year 9 pupils.

This change in the themes was supported by the reflective lesson notes from both the Year 5 and Year 9 teachers. For some of the Year 5 and the Year 9 pupils, the wool model broadened their understanding of DNA from a narrow idea that it can be used for identification, to appreciating its role in inheritance. For some of the Year 5 and the Year 9 pupils, the wool model also played the role of coalescing the concepts of gene and DNA (as in the interview excerpt from Jamie). These pupils realised that these two things are essentially different parts of the same thing and as a consequence, have the same function. Broadening pupils' understanding of DNA is part of the process of (and possibly an initial step towards) coalescing the concepts of genes and DNA and, therefore, the wool model played this role for both Year 5 and Year 9 pupils.

The Year 12 pupils were all studying biology and, unlike the younger children, generally had good understandings of the relationship between genes and DNA prior to instruction. As shown in the interview excerpts from Rena and Emily, however, the Year 12 pupils did not link their general understandings of genetics with proteins or the process of protein synthesis and then to phenotype (or the observable characteristics of organisms). We initially postulated that the role of the wool model for these pupils was to create networks of knowledge that linked concepts (genes and DNA) with the processes of protein synthesis to the observable characteristics of organisms (Table 2). Through an examination of the teacher's lesson notes and a reflection on the interview data, it became evident that the wool model itself was not extended to model the process of protein synthesis from the DNA code and, indeed, this is not readily possible with the simple model.

What we found is that the wool model was initially used to begin creating networks between concepts such as genes, DNA, allele and then the resultant discussion led to the explicit linking between these concepts and proteins, protein synthesis and phenotype. The teacher's awareness of the pupils' pre-instructional conceptions expressed in the interview also was likely to have contributed to this direction being taken in the classroom discussion. Regardless of this observation, however, we feel that the wool model did precipitate initial networks and provided a mechanism for further networks between concepts and processes related to genetics to be developed.

\section{Conclusion}

The findings suggest that the role of the wool model was largely determined by the pupils' prior knowledge about genes and DNA and that as the teachers were aware of the pupils' prior conceptions they adapted the model accordingly. The model was malleable and had multiple roles in learning for the pupils in the different years that reflected their developing conceptual understandings about genes and DNA. Rather than a domain general modelling capacity, the specific 
content knowledge within the domain of genetics seemed to be an important factor that had an impact on the way that the model was used by the teacher and the pupils in the learning process. For the Year 2 pupils the use of the model provided a concrete image and the language to describe a mechanism for the known concept of inheritance. For the Year 5 (and some Year 9) pupils the model helped to develop an association between the concepts of gene, DNA, living things and inheritance. For Year 9 (and some Year 5) participants the wool model coalesced the divergent concepts of gene and DNA. Finally, for the Year 12 pupils, the model initiated and consolidated networks of understanding related to genetics concepts and preceded further network creation to protein synthesis and characteristics.

\section{References}

Aubusson P J, Harrison A G and Ritchie S M (Eds) (2006) Metaphor and analogy in science education. Dordrecht, The Netherlands: Springer.

Dagher Z R (1994) Does the use of analogies contribute to conceptual change? Science Education, 78(6), 601-614.

Duit R (1991) On the role of analogies and metaphors in learning science. Science Education, 75, 649-672.

Harrison A G (2008) Teaching with analogies: Friends or foes? In: A G Harrison \& R K Coll (Eds), Using analogies in middle and secondary science classrooms (pp6-21). Thousand Oaks, CA: Corwin Press.

Harrison A G and Coll R K (Eds) (2008) Using analogies in middle and secondary science classrooms. Thousand Oaks, CA: Corwin Press.

Justi R and Gilbert J (2006) The role of analog models in the understanding of the nature of models in chemistry. In: P J Aubusson, A G Harrison and S M Ritchie (Eds), Metaphor and analogy in science education (pp119-130). Dordrecht, The Netherlands: Springer.

Merriam S B (1998) Qualitative research and case study applications in education ( $2^{\text {nd }}$ ed) San Francisco: Jossey-Bass.

Piaget J and Inhelder B (1974) The child's construction of quantities. London: Routledge.

Piaget J and Inhelder B (1976) The child's conception of space. London: Routledge and Kegan Paul.

Thiele R B, Venville G J and Treagust D F (1995) A comparative analysis of analogies in secondary biology and chemistry texbooks in Australian schools. Research in Science Education, 25, 221-230.

Treagust D F, Duit R, Joslin P and Lindauer I (1992) Science teachers' use of analogies: Observations from classroom practice. International Journal of Science Education, 14, 413-422.

Venville G, Gribble S J and Donovan J (2005) An exploration of young children's understandings of genetics concepts from ontological and epistemological perspectives. Science Education, 89(4), 614-633.

Wadsworth B J (2004) Piaget's theory of cognitive and affective development $\left(5^{\text {th }}\right.$ edn). Boston, MA: Allyn and Bacon.

Yin R K (2003) Case study research: Design and methods ( $3^{\text {rd }}$ ed). Thousand Oaks, CA: Sage.

Grady Venville (corresponding author) is Professor of Science Education in the Graduate School of Education, University of Western Australia, 35 Stirling Highway, Crawley, WA 6009, Australia. Email: grady.venville@ uwa.edu.au. Jenny Donovan is a Science Education Consultant and doctoral candidate, and lives in Queensland, Australia.
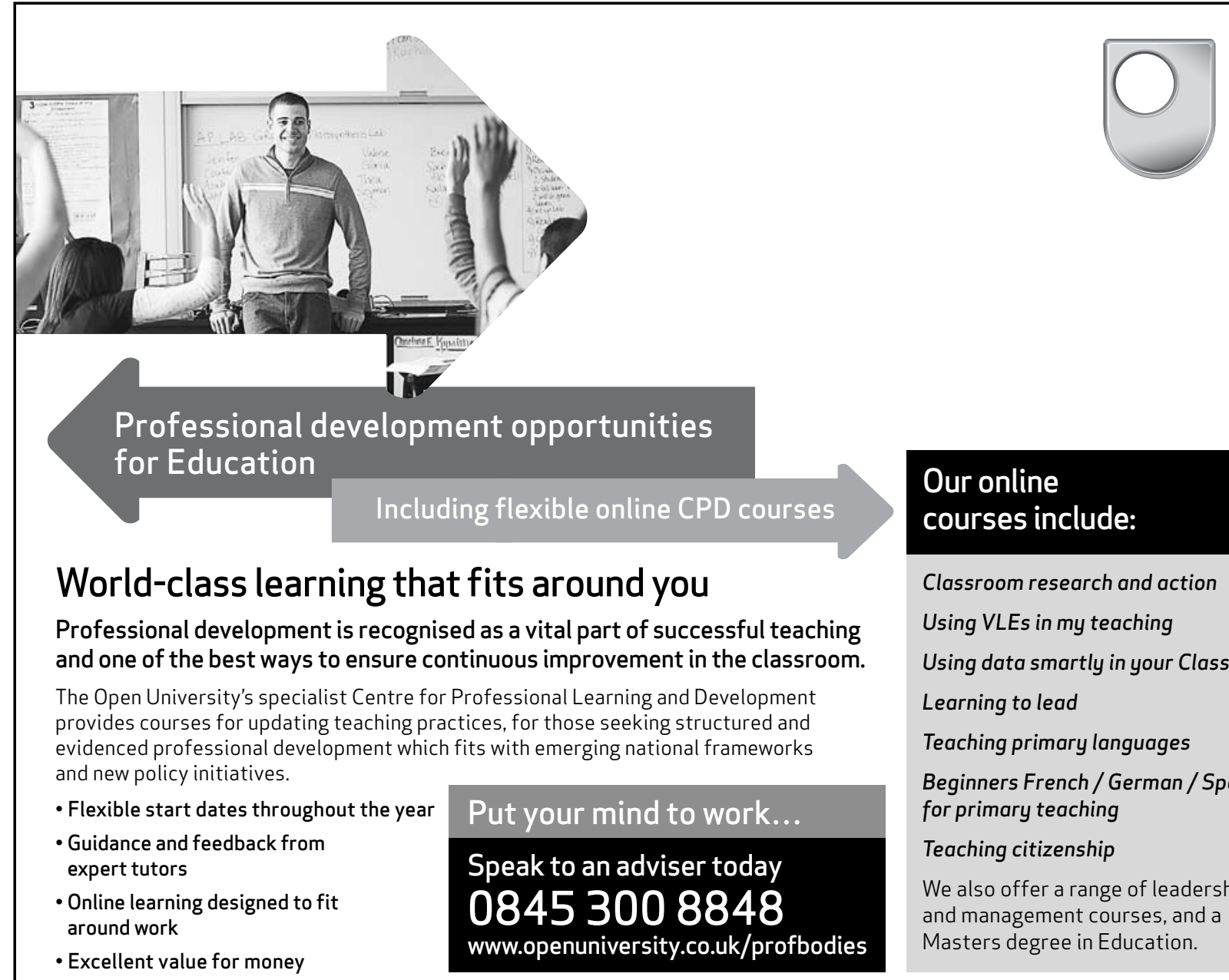

Professional development opportunities for Education

\section{World-class learning that fits around you}

Professional development is recognised as a vital part of successful teaching and one of the best ways to ensure continuous improvement in the classroom. evidenced professional development which fits with emerging national frameworks and new policy initiatives.

ughout the year

Online learning designed to fit

- Excellent value for money
Put your mind to work...

Speak to an adviser today 08453008848 www.openuniversity.co.uk/profbodies

\section{Our online} courses include:

Classroom research and action Using VLEs in my teaching Using data smartly in your Classroom Learning to lead

Teaching primary languages Beginners French / German / Spanish for primary teaching

\section{Teaching citizenship}

We also offer a range of leadership and management courses, and a Masters degree in Education. 
Copyright of Journal of Biological Education is the property of Institute of Biology and its content may not be copied or emailed to multiple sites or posted to a listserv without the copyright holder's express written permission. However, users may print, download, or email articles for individual use. 